\title{
Design Rule and Social Dimensions of the Bengkilas of Vernacular Limas Houses in South Sumatra
}

\author{
Ibnu Aziz ${ }^{\mathrm{a}, *}$, Ari Siswanto ${ }^{\mathrm{b}}$, Ngakan Putu Sueca ${ }^{\mathrm{c}}$, Dadang Hikmah Purnama ${ }^{\mathrm{d}}$ \\ ${ }^{a}$ Department of Architecture Engineering, Tridinanti University Palembang, Kapten Marzuki Street No. 2446, Palembang, 30129, Indonesia \\ ${ }^{b}$ Department of Architecture Engineering, Sriwijaya University, Raya Palembang Street Km. 32, Indralaya, 30662, Indonesia \\ ${ }^{c}$ Department of Architecture Engineering, Udayana University, P.B. Sudirman Street Km. 32, Denpasar, 80234, Indonesia \\ ${ }^{d}$ Department of Sociology, Sriwijaya University, Raya Palembang Street Km. 32, Indralaya, 30662, Indonesia \\ Corresponding author: ${ }^{*}$ ibnuaziz0307@gmail.com
}

\begin{abstract}
This article explores the guidelines used to theoretically and empirically determine the bengkilas' measurement of Limas house to understand how the social dimension is integrated into the vernacular housing design process. This goal was achieved by conducting a multi-case study, mixed methods, interviews with four interviewees chosen purposively because of their limas house ownership and recognition of expertise in its architecture, and measurements on 30 limas houses in Palembang, South Sumatra, Indonesia. The data was collected quantitatively through measurements of the dimensions of the house and qualitatively through interviews with community leaders. Previous research literature was also used to cross-examine various interviewees' statements. This literature was likely to be local studies that cannot be avoided due to the lack of international publications related to the limas house. The guideline used in determining the size of bengkilas is the dulang module system and the step count system. The social dimension can be seen from the priority of space to share food in the house based on the dish module. Based on the study results, a theory was developed which explained that the origins of bengkilas were semi-public space instead of social stratification. Governments trying to revitalize vernacular housing for reasons of tourism, culture, or preservation, can build on the findings of this study to build sustainable housing design. This article contributes to the understanding of vernacular design that exists today.
\end{abstract}

Keywords - Vernacular housing; bengkilas; dish module; revitalize; limas house.

\section{INTRODUCTION}

Increased awareness of the importance of vernacular architecture concerning sustainable development has triggered various studies on vernacular houses in various countries [1]. These studies seek to study the superior aspects of vernacular shelter and find out various aspects related to the purpose of preservation and adaptation to modern housing models. Multi-terrace houses are models of houses that are classified as rare in vernacular architecture. The existence of buildings with many terraces is often associated with land topology problems [2]. Therefore, it is possible that such houses are only found in mountainous areas. Even so, in Indonesia, three types of multi-terrace houses can be found: the limas house, Bubungan Tinggi house, and Tongkonan. The last house is the home of the people who live in the highlands in the southern peninsula of Sulawesi and can therefore be interpreted as adaptations to sloping topography.
However, the first two houses are houses of coastal communities, Palembang and Banjar, both of which are part of the Malay family.

Terrace houses are a common feature of Malay houses [3], but multi-terrace houses can only be found in Palembang and Banjar. The existence of this multi- terrace is considered more due to social factors than topography by referring to social stratification in societies that are familiar with complex government and political systems. However, social stratification theory has weaknesses because Malay society is a collective society. In a collective society, group norms and social harmony are highly prioritized, in contrast to individual societies that prioritize personal interests and justice [4]. When viewed from the perspective of social stratification, the existence of a multi-terrace house will cause problems because it will create an individualistic impression where the owner shows off his wealth to the surrounding society. Therefore, it is possible that social stratification is not the main goal of the existence of terraces in multi-terrace houses 
in collective societies. It can also be seen from Malay [13], Minangkabau [14], and Toraja houses [15]. We suspect that limas house can also be related to the anthropometry of the house's occupants. According to anthropometric theory, houses tend to be made based on the measurements of the human body [16]. This explains why many vernacular housings in Southeast Asia are elbow-shaped rather than curvilinear. Curvilinear form (curved, rounded) has no anthropometric relations with the human body [17].

Palembang City in South Sumatra is a city where limas houses are still commonly found. We focus on limas house because, based on the observations from Taal [5], there has been no construction of a new limas house since 1950 [5], [6]. Moreover, limas expert builders are increasingly disappearing, either because of old age and no heir or disappearing and possibly changing jobs. Taal [6] notes that in the early 1970s, there was only one sculpture expert left in Palembang. In the situation of limas houses that are no longer undergoing new construction while old buildings continue to diminish, it becomes important to carry out conservation efforts, including examining the principles that make up the proportions in limas buildings and the sociological content behind them. These proportions can also be identified by looking at the house's horizontal, sagittal, and vertical plane [7]. Symmetry is also related to the aesthetic principle of proportion [8], which can be applied to palaces in the Malay area [9] and some of the limas houses. The proportion size of a room can also effect the ventilation system. For cross ventilation in limas house to be effective, the room's depth must be at most five times the height of the room [10].

The previous research has identified simple ratios that apply to limas [11] based on the theory of proportions [12]. The results of this study found that limas architects use the ratio of $1: 1$ intensively together with other simple ratios, specifically $2: 3$. For bengkilas, it was found that $24.4 \%$ of level 1 bengkilas area was built at 2:3 ratio, 17.7\% of level 2 bengkilas at $1: 4$ and another $17.7 \%$ at $2: 3$, and $22.2 \%$ of level 3 bengkilas at 1:4. Furthermore, it was found that the most dominant simple ratio is in the floor and roof area, which reflects the function of the limas house as a private housing that allows residents to enjoy more in the house. In the end, it is not yet known on what basis the dimensions of this building are formed, especially one-dimensional parameters such as the room's length.

This paper aims to determine the meaning of the existence of terraces in multi-terrace houses in Indonesia by taking the case of Palembang Limas House. To achieve this goal, this study collects measurement data that is juxtaposed with expert information so that it is able to obtain an overview of the system used to determine the size of each terrace. Furthermore, the measurement results are interpreted from the socio-cultural perspective of the society. Specifically, this study focused on limas houses with three bengkilas construction (Fig. 1). A house with a three bengkilas construction was chosen because it is the most common type of limas found in South Sumatra. From the initial survey of researchers, obtained 50 limas houses at least 100 years old in the area of Seberang Ulu, Palembang City, the capital of South Sumatra province. Of these 50 limas houses, $30(60 \%)$ of them are three bengkilas limas.
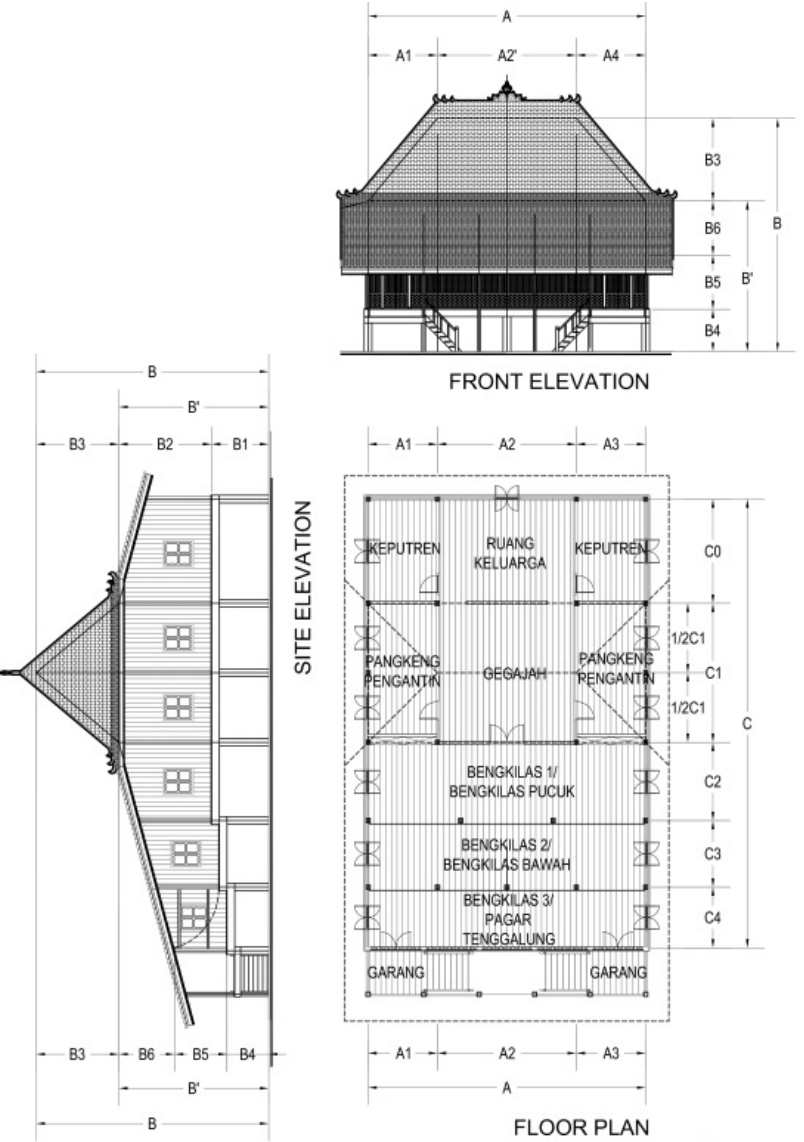

FRONT ELEVATION

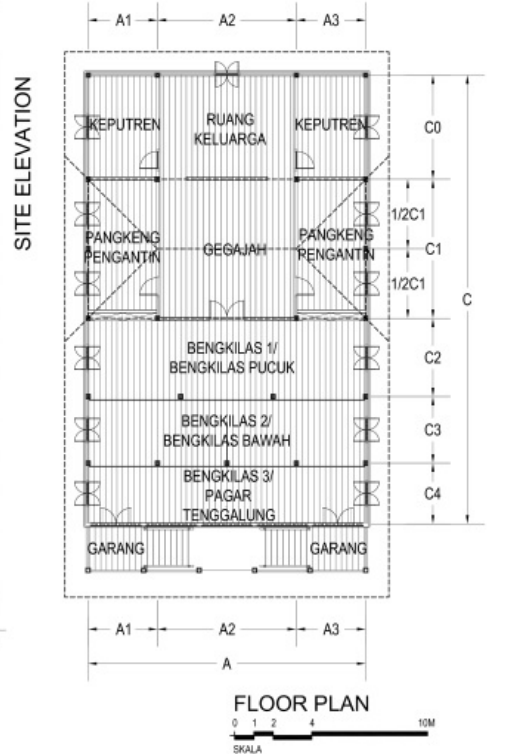

Fig. 1 Three bengkilas Limas House plan and instructions for measurement

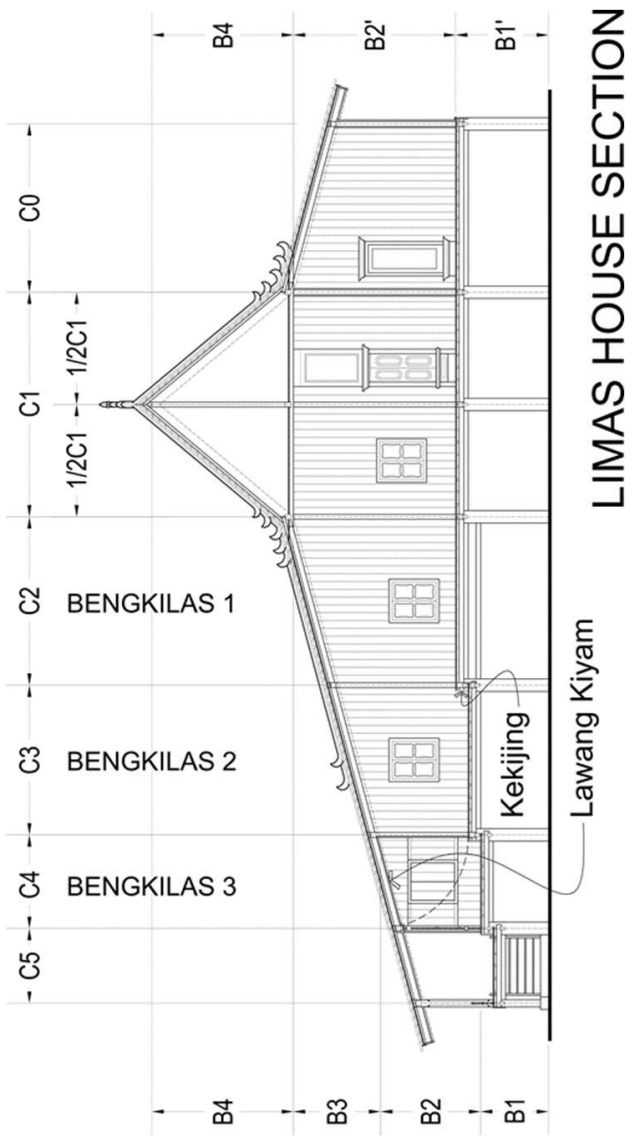

Fig. 2 Limas House Section 


\section{MATERIALS AND METHOD}

This research is a mixed-method multi-case study with four cultural experts in Palembang that was chosen purposively because of their ownership of the limas house and recognition of their expertise in the architecture of limas house. The number of interviewees is low because it is, as implied by Taal [5], limas knowledge is very rare. Moreover, our interviewees have high authoritative knowledge, so that they have high compatibility with the research topic.

As part of the mixed method, quantitative measurements on the dimensions of bengkilas and gegajah from eight types of existing limas houses with three bengkilas in Palembang City (covering a total of 30 houses), were also carried out.

Furthermore, we also use previous research literature to cross-examine a variety of interviewee statements. Previous literature used is likely to be local studies which cannot be avoided due to the lack of international publications related to the limas house.

The research location is Palembang City, the capital of South Sumatra Province. The city has a fairly large concentration of limas. The survey result of Aziz et al. [11] found 50 limas houses with a minimum age of 100 years. Some of these limas face the Musi River, the river that divides Palembang City and is also the widest river in Indonesia.

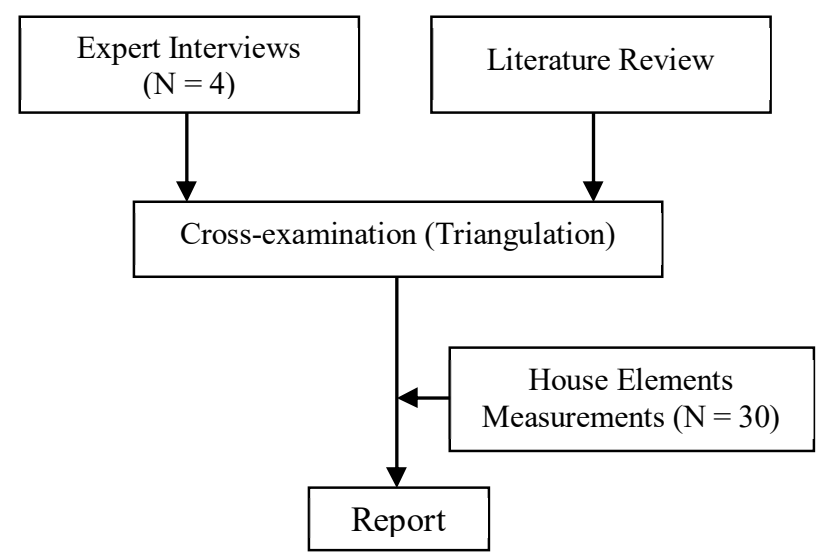

Fig. 3 Research Method Flow Chart

Data analysis in this research is qualitative and quantitative analysis. Simply put, we compare the interviewees' claims with quantitative data and interpret the results according to the comparison results. The interview itself is carried out indepth. Four guiding questions are used: (1) what are the spatial components of the limas house? (2) what is the current condition of the limas house in Palembang? (3) On what basis did the benkilas' measurement of limas house be determined? And (4) what is the social meaning contained in the limas house?. For the purpose of the present study, only the answers to questions (3) and (4) are analyzed, while questions (1) and (2) are for introductory questions.

\section{RESULTS AND DISCUSSION}

The main basis of determining the size of a limas is the dish row. One bengkilas has the size of one row, where one row consists of six dishes. One dish serves eight people who are sitting cross-legged around the dish. As a result, each dish can be a unit of measurement (module) to determine the size of a bengkilas floor area.

One dish module forms a box with concentric circles inside it. This concentric circle consists of one dulang in the middle, then a plate for side dishes, a plate for rice, and finally human. The following figure shows the size of one dish module. It can be said that one dish module has a diameter of $260 \mathrm{~cm}$. In line with this, an ideal bengkilas has a length of $6 \times 260=15.6 \mathrm{~m}$.

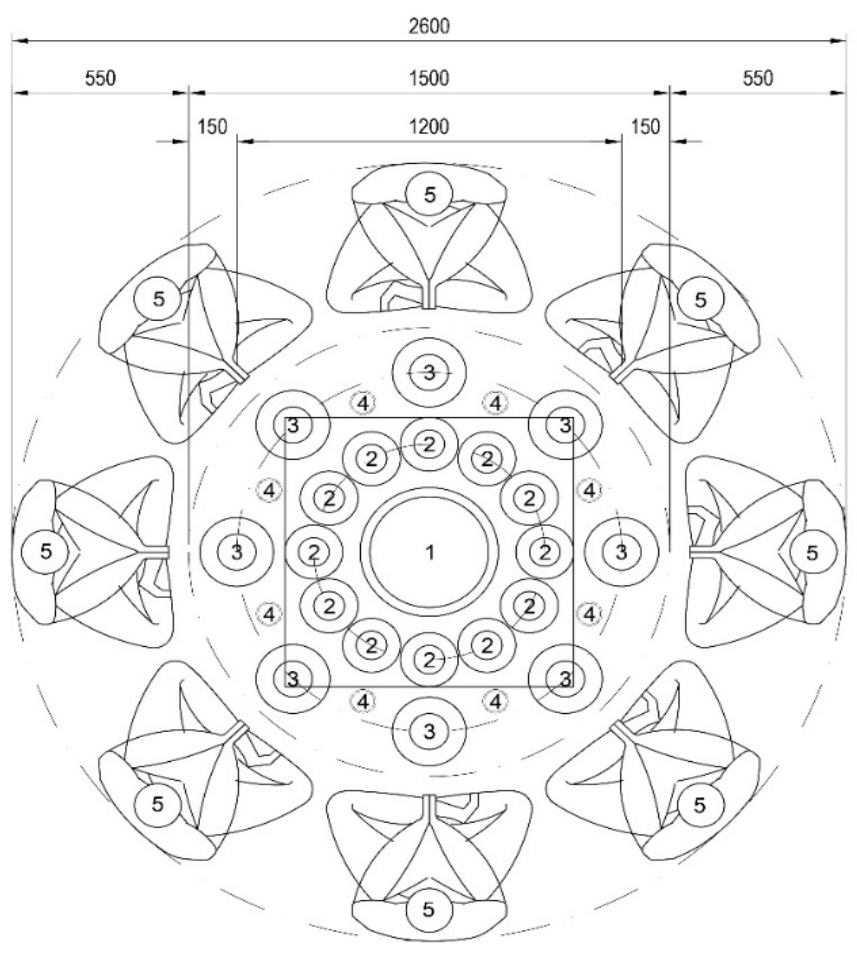

Fig. 4 Measurement of One Dish Module

Note: $1=$ dulang for rice $\mathrm{d}=43 \mathrm{~cm}, 2$ = plates for side dishes, vegetables, and fruits $\mathrm{d}=18 \mathrm{~cm}, 3=$ plates for eating $\mathrm{d}=23 \mathrm{~cm}, 4=$ glasses of drinking water, $5=$ people sitting cross-legged. All measurements are in $\mathrm{mm}, \mathrm{d}=$ diameter

However, the data from Table 1 shows that this rule was not fulfilled in the three bengkilas limas houses. None of the three bengkilas limas houses adhere to a ratio of 1: 6 . The highest ratio is 1: 4, which can only be found in bengkilas III. This means that, on average, there are only four dishes in a row in bengkilas III. The ratio at bengkilas II is lower at 1: 3 while at bengkilas I is only 1: 1 .

TABLE I

CALCULATION OF BENGKILAS DIMENSION

\begin{tabular}{|c|c|c|c|c|c|}
\hline \multirow{2}{*}{ Item } & \multirow{2}{*}{$\begin{array}{c}\text { Length } \\
\text { (cm) }\end{array}$} & \multirow{2}{*}{$\begin{array}{c}\text { Width } \\
\text { (cm) }\end{array}$} & \multicolumn{2}{|c|}{ Dish Module $(/ 260 \mathrm{~cm})$} & \multirow{2}{*}{$\begin{array}{l}\text { Ratio } \\
\text { (DM } \\
\text { L/W) }\end{array}$} \\
\hline & & & Length & Width & \\
\hline \multicolumn{6}{|c|}{ Bengkilas I } \\
\hline Type I & 960 & 840 & 3.69 & 3.23 & 1.14 \\
\hline Type II & 960 & 680 & 3.69 & 2.62 & 1.41 \\
\hline Type III & 1080 & 720 & 4.15 & 2.77 & 1.50 \\
\hline Type IV & 1050 & 690 & 4.04 & 2.65 & 1.52 \\
\hline Type V & 1050 & 700 & 4.04 & 2.69 & 1.50 \\
\hline Type VI & 960 & 670 & 3.69 & 2.58 & 1.43 \\
\hline Type VII & 840 & 740 & 3.23 & 2.85 & 1.14 \\
\hline Type VIII & 900 & 700 & 3.46 & 2.69 & 1.29 \\
\hline Average & 975.00 & 717.50 & 3.75 & 2.76 & 1.37 \\
\hline
\end{tabular}




\begin{tabular}{llllll}
\hline \multicolumn{3}{l}{ Bengkilas II } & & & \\
\hline Type I & 960 & 360 & 3.69 & 1.38 & 2.67 \\
Type II & 960 & 260 & 3.69 & 1.00 & 3.69 \\
Type III & 1080 & 280 & 4.15 & 1.08 & 3.86 \\
Type IV & 1050 & 280 & 4.04 & 1.08 & 3.75 \\
Type V & 1050 & 320 & 4.04 & 1.23 & 3.28 \\
Type VI & 960 & 300 & 3.69 & 1.15 & 3.20 \\
Type VII & 840 & 300 & 3.23 & 1.15 & 2.80 \\
Type VIII & 900 & 260 & 3.46 & 1.00 & 3.46 \\
Average & $\mathbf{9 7 5 . 0 0}$ & $\mathbf{2 9 5 . 0 0}$ & $\mathbf{3 . 7 5}$ & $\mathbf{1 . 1 3}$ & $\mathbf{3 . 3 4}$ \\
\hline Bengkilas III & & & & \\
\hline Type I & 960 & 240 & 3.69 & 0.92 & 4.00 \\
Type II & 960 & 220 & 3.69 & 0.85 & 4.36 \\
Type III & 1080 & 240 & 4.15 & 0.92 & 4.50 \\
Type IV & 1050 & 220 & 4.04 & 0.85 & 4.77 \\
Type V & 1050 & 240 & 4.04 & 0.92 & 4.38 \\
Type VI & 960 & 210 & 3.69 & 0.81 & 4.57 \\
Type VII & 840 & 220 & 3.23 & 0.85 & 3.82 \\
Type VIII & 900 & 240 & 3.46 & 0.92 & 3.75 \\
Average & $\mathbf{9 7 5 . 0 0}$ & $\mathbf{2 2 8 . 7 5}$ & $\mathbf{3 . 7 5}$ & $\mathbf{0 . 8 8}$ & $\mathbf{4 . 2 7}$ \\
\hline
\end{tabular}

More than that, if seen from the width of the bengkilas, then one bengkilas can accommodate 2-3 rows, each 3-4 dishes in bengkilas I. On average, in bengkilas II and III, it can accommodate only 1 row with 3-4 dishes per row. It should be noted that bengkilas I in three bengkilas limas house is actually bengkilas I and II in four bengkilas limas house. That is, if applied to a house with four bengkilas, the capability of bengkilas I to accommodate a row of dishes can decrease from 2-3 to only 1 row of dishes. In this case, the three bengkilas limas house has the advantage of being able to accommodate more dishes than the four bengkilas limas house. Overall, this also means that the rules of one row per bengkilas are fulfilled; it is just that the number of dishes for one row is not met.

Even so, Table 2 shows that these two-row rules are not fulfilled. Gegajah in the limas house with three bengkilas takes the shape of a square with a ratio of 1:1. If you follow the rules twice, then the ratio of gegajah should be $2: 6=1: 3$. Moreover, the length of the gegajah cannot accommodate two rows of dish. Gegajah dimension can only accommodate one row with one dish.

The small size of gegajah at three bengkilas limas house can be interpreted because of the changing role of space. Residents no longer use gegajah room as the main room but instead chose bengkilas I. Gegajah switches function as a space between two rooms. This is different from the situation in the past where the gegajah room became the main room, so that it was larger than bengkilas.

TABLE II

CALCULATION OF GEGAJAH DimENSION

\begin{tabular}{|c|c|c|c|c|c|}
\hline \multirow[b]{2}{*}{ Item } & \multirow{2}{*}{$\begin{array}{c}\text { Length } \\
\text { (cm) }\end{array}$} & \multirow{2}{*}{$\begin{array}{c}\text { Width } \\
\text { (cm) }\end{array}$} & \multicolumn{2}{|c|}{ Dish Module $(/ 260 \mathrm{~cm})$} & \multirow{2}{*}{$\begin{array}{l}\text { Ratio } \\
\text { (DM } \\
\text { L/W) }\end{array}$} \\
\hline & & & Length & Width & \\
\hline \multicolumn{6}{|l|}{ Gegajah } \\
\hline Type I & 320 & 280 & 1.23 & 1.08 & 1.14 \\
\hline Type II & 320 & 360 & 1.23 & 1.38 & 0.89 \\
\hline Type III & 360 & 360 & 1.38 & 1.38 & 1.00 \\
\hline Type IV & 350 & 390 & 1.35 & 1.50 & 0.90 \\
\hline Type V & 350 & 380 & 1.35 & 1.46 & 0.92 \\
\hline Type VI & 320 & 320 & 1.23 & 1.23 & 1.00 \\
\hline
\end{tabular}

\begin{tabular}{llllll} 
Type VII & 280 & 300 & 1.08 & 1.15 & 0.93 \\
Type VIII & 300 & 400 & 1.15 & 1.54 & 0.75 \\
Average & $\mathbf{3 2 5 . 0 0}$ & $\mathbf{3 4 8 . 7 5}$ & $\mathbf{1 . 2 5}$ & $\mathbf{1 . 3 4}$ & $\mathbf{0 . 9 4}$ \\
\hline
\end{tabular}

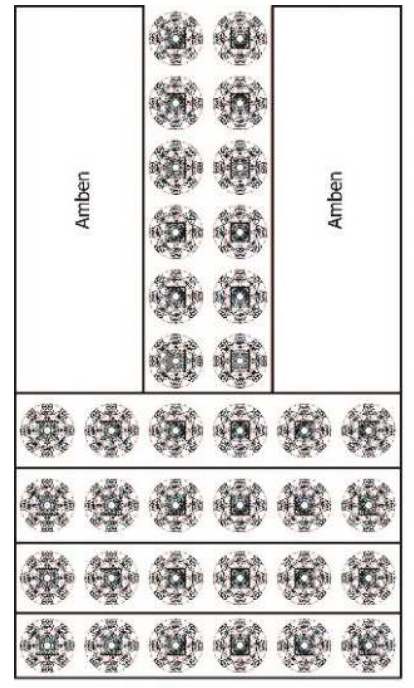

TEORITIS

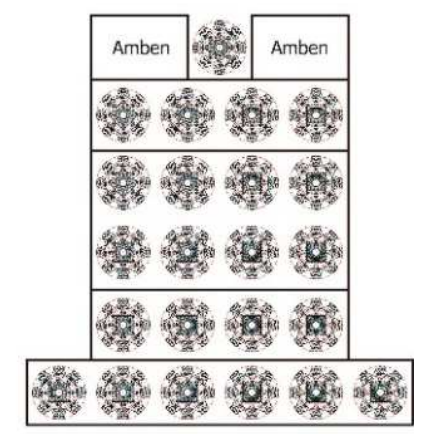

EMPIRIS
Fig. 5 Theoretical and empirical dulang layout, the total of dishes for eight people in Limas Three Bengkilas

The interviewee also stated that one limas house should ideally be able to accommodate 30 dishes. Since each dish can accommodate eight people, in total limas house can accommodate 240 people sitting around the dish. This value is obtained from three bengkilas and one gegajah so that five rows can be obtained with each of six dishes.

TABLE III

CALCULATION OF TOTAL Dish COUNTS

\begin{tabular}{|c|c|c|c|c|c|c|}
\hline \multirow{2}{*}{ Limas } & \multicolumn{3}{|c|}{ Bengkilas Bengkilas Bengkilas } & \multirow{2}{*}{ Gegajah } & \multirow{2}{*}{ Total } & \multirow{2}{*}{ People } \\
\hline & I & II & III & & & \\
\hline Type I & 11.93 & 5.11 & 3.41 & 1.33 & 21.78 & 174.20 \\
\hline Type II & 9.66 & 3.69 & 3.12 & 1.70 & 18.18 & 145.42 \\
\hline Type III & 11.50 & 4.47 & 3.83 & 1.92 & 21.73 & 173.82 \\
\hline Type IV & 10.72 & 4.35 & 3.42 & 2.02 & 20.50 & 164.02 \\
\hline Type V & 10.87 & 4.97 & 3.73 & 1.97 & 21.54 & 172.31 \\
\hline Type VI & 9.51 & 4.26 & 2.98 & 1.51 & 18.27 & 146.18 \\
\hline Type VII & 9.20 & 3.73 & 2.73 & 1.24 & 16.90 & 135.20 \\
\hline Type VIII & 9.32 & 3.46 & 3.20 & 1.78 & 17.75 & 142.01 \\
\hline Average & 10.34 & 4.26 & 3.30 & 1.68 & 19.58 & 156.64 \\
\hline
\end{tabular}

Table 3 shows that the existing three bengkilas limas cannot achieve this amount. The average house is only able to provide 20 dishes with an average of 157 people. Type I and III houses have a relatively large capacity because of the large bengkilas I. Even so, this capacity is still 172-174 people, far below 240 people who could ideally be accommodated in a limas house.

The use of the dish module in the limas house aims to ensure that there is sufficient space for community dining activities. This joint dining (alms) activity takes place when the house is finished built, circumcision of the resident's child, wedding of the resident, praying for the deceased, or other events organized by the residents, inviting the wider community. The existence of a limit of 240 people can indicate the size of the existing community. In the past, this 240 people could cover a wider area than now and could be 
interpreted as a village size.

When compared to the four bengkilas limas house, as long as the total size is the same, the three bengkilas limas house can accommodate more people. This is because the bengkilas I and II in the four bengkilas limas house combined to become bengkilas I at three bengkilas limas house. The loss of barriers leaves extra room for food rows.

The existence of fusion of bengkilas in three bengkilas limas house, in turn, defies caste theory. According to caste theory, the five bengkilas in limas represent Palembang's Malay social stratification. The five classes in this social stratification are the sultan, prince, raden, kemas, and kiagus [18]. At the level of social status, it is clear that the number of social status holders will increase in line as the status lowers. There was only one sultan, but there were several princes, followed by more radens, and so on. On the other hand, in the three bengkilas, the highest bengkilas (bengkilas I) becomes the largest bengkilas to accommodate more people. This clearly contradicts the social stratification system in caste theory. Furthermore, the use of a dish module consisting of eight people also opposes caste theory because it does not distinguish between modules. There are no special modules for sultans, princes, radens, and so on. There is only one module that applies to all bengkilas.

If so, then what is the function of bengkilas if not for social stratification? In our opinion, bengkilas acts more as a system of transition between private and public space. Rather than as social stratification, the highest bengkilas becomes a semiprivate domain where only families of residents can eat in this area. Other communities can be in the lower bengkilas. However, this can be situational, where if the upper part is not full, the community can fill in the upper part. In the context of the nobility, this cannot be distinguished from caste theory because of the farther a person's kinship with the king, the lower the social status. However, the explanation of the transitional theory is more universal because it can also apply to limas houses in the community and in accordance with the dish module, which is the basis of anthropometry in building limas houses. This theory also explains why people are not too concerned about the number of bengkilas in social norms, so there are houses with two bengkilas, three bengkilas, up to five bengkilas. Because of the amount of bengkilas is linear with costs [5], this is more about economic problems than social problems. Of course, rich people can choose to build a house with five bengkilas, but this has nothing to do with the nobility/social status that exists in the community around the house. In other words, the reason for the existence of bengkilas is more an individual reason than a social one.

The application dish module is not unique to limas house. In the Malay community in general, the dish module is the basis for building a house. In Malaysia, one dish module consists of only four people with a diameter of about 2 meters and is used to determine the terrace area [13].

The importance of giving food to many people in the community in the design of bengkilas reflects the strong social aspects in influencing architecture. In a study of the Tigray community, Ethiopia, Lyons [19] found that the wide serving of food in the community had an important role in maintaining social status and membership in the community of mutual cooperation. The same thing can also be true of why giving food to many people is the basis for the design of bengkilas. In this case, the homeowner makes every effort to ensure that all people involved in mutual cooperation of building the house can be accommodated in the house that has been built with the activity of eating together as a form of gratitude. For the next time after the house is built, bengkilas can be a means of entertaining the community for various activities. This method allows homeowners to remain accepted by the community and maintain their social status.

Although both of them use the dish module, the eightperson dish module in limas is different from the Malay, which uses the four-person dish module for Malaysia's Malay society [13]. Four-person dish modules are also commonly used in pesantren communities. On the other hand, the eightperson dish module at the limas house has similarities to the dish module in the Megibung tradition in the Bali community [20]. It also might be because of the Buddhist influence where the pagoda has an octagonal-shaped roof which can be interpreted as the eight paths of kindness [21].

The reason for choosing eight people, rather than four, seems to indicate a high degree of collectivism. Eight people is the maximum amount that can be accommodated by a dulang that one person can carry. Palembang people seem to be trying to maximize the togetherness within the anthropometric boundaries in bengkilas design. Of course, the amount can be even more with a row system based on the tradition of the ngeliwet in Sundanese society. This is less collective because only two people face each other, and there is an extreme point that creates a degree difference. In the circular shape, everyone faces, and there is no end in this circle, indicating equality. Again, this cannot be explained through caste theory.

Two facts support the theory of collectivity as an explanation for the choice of eight people. First, the teachings of Islam, which is the religion of the absolute majority of limas residents, teach eating in the congregation. Two main hadiths discuss the number of people to eat together [22]. Hadith by Bukhari No. 5392 states that "food for two people is enough for three people, and food for three people is enough for four people," while Hadith by Muslim No. 2059 states, "food for one people is enough for two people, food for two people is enough for four people, food for four people is enough for eight people". Malay society seems to adopt Bukhari's perspective while Palembang people take Muslim's perspective.

The second fact is the occurrence of cultural transformation in the Balinese and Sasak people. Kasih et al. [20] state that the Megibung dish module was eight people in the past, but in the present time, there are only four people. This can be interpreted as the fading of togetherness in a society where fewer people want to eat together. That is, eight people contain more togetherness than four people.

This explanation can then be harmonized with the motto "Batanghari Sembilan" which is the motto of the Palembang people, describing the existence of eight rivers that are branches of the Musi river. This motto is a modern attachment to the principle of togetherness based on eight people in Palembang's collectivist system.

In conclusion, the sociological dimension related to anthropometric characteristics of bengkilas is a strong sense of togetherness. This strong togetherness is realized in the maximized dish module design. This togetherness is 
strengthened by expanding the upper bengkilas to be wider in the three bengkilas limas house. This is against the caste theory, which states that the function of bengkilas is for social stratification. Even so, the size of bengkilas in the threebengkilas limas house has been reduced from the ideal size to accommodate fewer people than it should be, which are 240 people to only 156 people.

\section{CONCLUSION}

This research focuses on the relation between the guidelines for building limas house and the social dimension of the vernacular architecture of three-bengkilas limas house in Palembang, South Sumatra. It was found that there are some rules in determining the dimensions of bengkilas, private spaces (gegajah), roof truss, and stairs' step. The rules in determining the dimensions of bengkilas and gegajah are not strictly adhered to by the 30 limas examined in this study. Nevertheless, the basic rules are still adhered to with food module as a basis for determining the size of bengkilas and gegajah. Sociologically, this reflects the meaning of high collectivity in Palembang community. The sense of togetherness is reflected in the maximum use of space in the circular area of dulang to create optimal group cohesion by utilizing the crops that are to be shared. Further interviews about the sociological or philosophical aspects can be conducted on homeowners with basic knowledge obtained from the few interviewees in this study, such as how the community interacts in celebration activities between bengkilas.

\section{ACKNOWLEDGMENT}

The authors are grateful to A. Malik Abdul Aziz, S.T., M. Aidil S.T., and Efriyanti S.T., who always assist and help collect data in the completion of this journal. The Dikti DPRM supported this work by providing the opportunity to take part in the Doctoral Dissertation Research

\section{REFERENCES}

[1] N. Abdul Majid, Z. Denan, Z. Abdul Rahim, N. Mohd Nawawi, and S. Hazman, "Sustainability concepts in Malay and aceh traditional houses," Plan. Malaysia J., vol. 15, May 2017, doi: 10.21837/pmjournal.v15.i6.216.

[2] Kolb, Michael J. "Diachronic Design Changes in Heiau Temple Architecture on the Island of Maui, Hawai'i." Asian Perspectives, vol. 31, no. 1, 1992, pp. 9-37. JSTOR, www.jstor.org/stable/42928255. Accessed 27 Aug. 2021.

[3] T. Kubota and S. Ahmad, "Wind Environment Evaluation of Neighborhood Areas in Major Towns of Malaysia," J. Asian Archit. Build. Eng., vol. 5, no. 1, pp. 199-206, 2006, doi: 10.3130/jaabe.5.199.

[4] H. C. Triandis, "Individualism-Collectivism and Personality," J. Pers., vol. 69, no. 6, pp. 907-924, 2001, doi: https://doi.org/10.1111/14676494.696169 .

[5] S. Taal, "The limas house of Palembang," in Indonesian Houses: Tradition and Transformation in Vernacular Architecture, 2nd ed., vol.
2, R. Schefold, P. J. M. Nas, and G. Domenig, Eds. NUS Press, 2008, pp. 363-389.

[6] S. Taal, "Change and Diversification in Form and Function of the Limas House of Palembang," in Indonesian Houses: Tradition and Transformation in Vernacular Architecture, R. Schefold, P. J. M. Nas, and G. Domenig, Eds. 2004, pp. 195-215.

[7] R. Alasmar, "Philosophy and Perception of Beauty in Architecture," Am. J. Civ. Eng., vol. 7, no. 5, pp. 126-132, 2019, doi: 10.11648/j.ajce.20190705.12.

[8] C. Chen and J. Zuo, "The Symmetrical Beauty and Its Cultural Connotation of Lingnan Architecture," in Advances in Social Science, Education and Humanities Research (ASSEHR), 2018, vol. 291, pp. 143-149, doi: 10.2991/meeah-18.2018.25.

[9] T. A. Q. R. A. Kadir, P. S. J. Kassim, and N. S. A. Latip, "Identity, tradition and the city: Dichotomies and realities of creating an Urban language of the Malay palace," Plan. Malaysia, vol. 16, no. 1, pp. 265280, 2018, doi: 10.21837/pmjournal.v16.i5.430.

[10] A. Baghaei Daemei, P. Haghgooy Osmavandani, and M. Samim Nikpey, "Study on Vernacular Architecture Patterns to Improve Natural Ventilation Estimating in Humid Subtropical Climate," Civ. Eng. J., vol. 4, no. 9, p. 2097, 2018, doi: 10.28991/cej-03091142.

[11] I. Aziz, A. Siswanto, N. P. Sueca, and D. H. Purnama, "The tradional architecture of palembang limas house evaluation of physical proportion of Palembang limas house with three Bengkilas in Seberang Ulu Palembang," Int. J. Eng. Adv. Technol., vol. 9, no. 1, pp. 36313635, 2019, doi: 10.35940/ijeat.A2702.109119.

[12] F. Ching, L. Roth, and S. Rassmussen, Introduction to Architecture Proportion and Scale. 2012.

[13] S. I. Arrifin, "Made to Order - A Place Called Home," in Southeast Asian Houses: Expanding Tradition, S. R. Ju, Ed. Seoul: Seoul Selection, 2017

[14] R. Fitriza, D. Afriyani, M. Turmudi, and D. Juandi, "The Exploration of Ethno-Mathematics Embedded on Traditional Architecture of Rumah Gadang Minangkabau," in Advances in Social Science, Education and Humanities Research, 2018, vol. 160, pp. 270-276, doi: 10.2991/incomed-17.2018.57.

[15] R. Muslimin, "Toraja glyphs: An ethnocomputation study of passura Indigenous icons," J. Asian Archit. Build. Eng., vol. 16, no. 1, pp. 3944, 2017, doi: 10.3130/jaabe.16.39.

[16] R. Tomovska and A. Radivojević, "Tracing sustainable design strategies in the example of the traditional Ohrid house," J. Clean. Prod., vol. 147, pp. 10-24, 2017, doi: https://doi.org/10.1016/j.jclepro.2017.01.073.

[17] O. Sukalo, "Conceptual narratives, ecological heeds, social purposes and subjective ends of natural building movement," Facta Univ. - Ser. Archit. Civ. Eng., vol. 14, no. 2, pp. 201-221, 2016, doi: 10.2298/fuace1602201s.

[18] D. Setyawati, Sariyatun, and N. Suryani, "Ilir and Uluan : Polarization and Hierarchy of Socio-Political Leadership of Malay-Java in Palembang Sultanate in the 19th Century," in Advances in Social Science, Education and Humanities Research (ASSEHR), 2018, vol. 154, pp. 139-143.

[19] D. Lyons, "End of an Era : Diversity in Former Feudal Landscapes An Ethnoarchaeological Study of Powerful Places in Tigray, Ethiopia. Calgary," 2008.

[20] L. S. Kasih, G. W. Bayu, and I. N. L. Jayanta, "the Ethnopedagogy Study on the "Megibung' Tradition in Karangasem," J. Filsafat Indones., vol. 2, no. 3, pp. 103-109, 2019, doi: 10.23887/jfi.v2i3.22154.

[21] D. Sharma, "Architectural Conservation of Decorative Timber Windows and Ornamental Columns at Buli Monastery," Am. J. Civ. Eng. Archit., vol. 5, no. 5, pp. 204-207, 2017, doi: 10.12691/ajcea-5$5-4$

[22] M. Tuasikal, "Makan Berjamaah (Collective Dining)," https://rumaysho.com/3255-makan-berjamaah.html. 